\title{
Geleneksel tarhana üretiminde kinoa ununun kullanımı
}

\section{Usage of quinoa flour in traditional tarhana production}

\author{
Gamze ÜÇOK $^{1^{*}}$ D Tekmile CANKURTARAN $^{1}$ iD Mustafa Kürşat DEMiR $^{1}$ \\ ${ }^{1}$ Necmettin Erbakan Üniversitesi, Mühendislik ve Mimarlık Fakültesi, Gıda Mühendisliği Bölümü
}

\section{To cite this article:}

Üçok, G., Cankurtaran, T. \&

Demir, M.K. (2019).

Geleneksel tarhana

üretiminde kinoa ununun

kullanımı. Harran Tarım ve

Gıda Bilimleri Dergisi, 23(1):

22-30. DOI:

$10.29050 /$ harranziraat.4023 50

Address for Correspondence: Gamze ÜÇOK

e-mail:

gozugur@konya.edu.tr

\section{Received Date:}

06.03.2018

Accepted Date:

09.11.2018

(C) Copyright 2018 by Harran University Faculty of Agriculture. Available on-line at www.dergipark.gov.tr/harranziraat

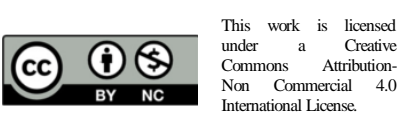

\section{öz}

Bu çalışmada tarhananın bazı kalite özelliklerini geliştirmek amacıyla kinoa ununun kullanımı araştırılmıştır. Bu amaçla 6 farklı oranda (\% 0, 20, 40, 60, 80 ve 100) kinoa unu, buğday unuyla ikame edilerek, tarhana üretiminde kullanılmıştır. Tarhana örneklerinde bazı fiziksel, kimyasal ve duyusal özellikler araştırılmıştır. Kinoa unu ikamesi ile genel olarak tarhana örneklerinin $L^{*}, a^{*}$ ve $b^{*}$ değerlerinin azaldığı belirlenmiştir. Tarhana formülasyonlarında kinoa unu miktarının artmasıyla, kül, protein, yağ, fitik asit ve toplam fenolik madde içerikleri artarken, viskozite değerlerinin azaldığı tespit edilmiştir. En yüksek viskozite değeri kontrol örneğinde belirlenmiş olup, kinoa unu ikamesi ile örneklerin vizkozite değerlerinde düşüş gözlenmiştir. Duyusal analiz sonuçlarına göre, kinoa unu kullanımının tarhana formülasyonlarının genel kabul edilebilirliğinde önemli bir etkisinin olmadığı görülmüştür.

Anahtar Kelimeler: Kinoa, Tarhana, Renk, Fitik asit, Duyusal özellikler

\section{ABSTRACT}

In this study, the usage of quinoa flour was investigated to improve some quality parameters of the tarhana. For this purpose, six different ratios of quinoa flour $(0,20,40$, $60,80$ and $100 \%)$ which were replaced by the wheat flour were used to produce tarhana samples. Some physical, chemical and sensory properties of tarhana samples were investigated. Generally, quinoa flour substitution decreased $L^{*}, a^{*}$ and $b^{*}$ values of the tarhana samples. Increasing amount of quinoa flour in tarhana formulations were resulted in higher ash, protein, fat, phytic acid, total phenolic contents and lower viscosity values. The highest viscosity value was determined in the control sample and the viscosity values decreased with the quinoa flour substitution. According to sensory analysis results, usage of quinoa flour has no significant impact in the overall acceptability of tarhana formulations.

Key Words: Quinoa, Tarhana, Colour, Phytic acid, Sensory properties

\section{Giriş}

Tarhana; buğday ürünlerinin yoğurt, domates, biber, soğan ve çeşitli baharatlarla yoğurulup 1-7 gün arasında fermente edilerek tüketilen geleneksel bir Türk lezzetidir (ibanoğlu ve ark., 1999). Asidik ve ekşi bir tada sahip olan tarhana, çorba yapımında kullanılmaktadır. Proteinlerin ve vitaminlerin önemli bir kaynağı olması nedeniyle, özellikle çocukların ve yaşlıların beslenmesinde büyük öneme sahiptir (Dağlıoğlu, 2000).
Türkiye'de genel olarak ev yapımı tarhana tüketimi yaygın olmakla birlikte endüstriyel üretimi de gün geçtikçe artış göstermektedir (ibanoğlu ve Maskan, 2002; Bilgiçli, 2009). Düşük $\mathrm{pH}$ (3.8-4.2) ve düşük nem içeriği (\%6-9) tarhanayı, patojen ve diğer mikroorganizmalara karşı güvenli hale getirmektedir. Higroskobik özelliğe sahip olmaması nedeniyle 1-2 yıl herhangi bir bozulma olmaksızın muhafaza edilebilmektedir (ibanoğlu ve ark., 1999). İçerdiği zengin besin bileşenleri ile insan beslenmesinde önemli rol 
oynamaktadır. İçeriğindeki undan gelen bitkisel proteinler ve yoğurttan gelen hayvansal proteinlerin birbirini tamamlaması ve fermente bir ürün olması tarhananın sindirilebilirliğini ve biyoyararlılı̆ını arttırmaktadır (Çevik, 2016). Literatürde tarhana veya tarhana benzeri ürünlerin üretiminde, besinsel içeriğinin zenginleştirilmesi ve fonksiyonel özelliklerinin geliştirilmesi amacıyla una alternatif olarak soya, mercimek, nohut, ruşeym, kepek, mısır, arpa, tam buğday unu ve bulgur kullanmıştır (Bilgiçli, 2009).

Kinoa olarak bilinen Chenopodium quinoa Willd., kazayağıgiller (Chenopodiaceae) familyasından tek yıllık bir bitki olup, son yıllarda insan ve hayvan beslenmesi üzerine yoğun çalışmalar yapılan bir türdür (Kaya, 2010; Koyun, 2013; Tan ve Yöndem, 2013). Kinoa, gluten içermediği için karabuğday ve amarant gibi pseudo-tahıl (tahıl benzeri) grubuna dahil edilmektedir ve glutensiz diyetlerde rahatlıkla kullanılabilmektedir (Alvarez-Jubete ve ark., 2009; Paśko ve ark., 2009). Gerek insan beslenmesinde önemli yeri olan protein, diyet lifi, esansiyel yağ asitleri, mineraller, vitaminler ve biyoaktif bileşenlerce zengin olması, gerekse iyi bir enerji kaynağı olması, kinoayı, yaygın olarak kullanılan diğer tahıl çeşitlerinden farklı kılmaktadır (Valencia-Chamorro, 2003; Alvarez-Jubete ve ark., 2010). Kinoanın protein içeriği kuru maddede (km) \%8 ile 22 arasında değişim göstermekte olup, bu proteinlerin çoğu embriyo kısmında lokalize olmuştur. Tahıllarda düşük miktarlarda bulunan lisin aminoasidi bakımından oldukça zengindir. Önemli miktarda metiyonin ve sistein içermesi bakımından birçok baklagilin iyi bir tamamlayıcısıdır (Doğan ve Karwe, 2003; Jancurová ve ark., 2009; Koyun, 2013). Yaklaşık olarak \%67-74 oranında karbonhidrat içeriğine sahiptir, bunun \%52-60'lık kısmını nişasta oluşturmaktadır. Az miktarda da monosakkarit (\%2), lif (\%2.5-3.9) ve pentozan (\%2.9-3.6) bulunmaktadır (Valencia-Chamorro, 2003). Esansiyel aminoasitler ve doymamış yağ asitlerince zengin bir içeriğe sahip olan kinoanın yağ asidi kompozisyonu, soya yağına benzemektedir (Ranhotra ve ark., 1993; ValenciaChamorro, 2003; Park ve Morita, 2004; Ng ve ark., 2007). Kinoa taneleri yaklaşık olarak \%6-8 oranında lipit içermekte olup, bu lipitlerin büyük çoğunluğunu linoleik ( \%52) ve linolenik asitler ( \%40) gibi esansiyel yağ asitleri oluşturmaktadır (Valencia-Chamorro, 2003; Park ve Morita, 2004). Kinoada doğal antioksidanların, özellikle de E vitamininin yüksek miktarda olması (yaklaşık 700 ppm $\alpha$-tokoferol ve 840 ppm $\gamma$-tokoferol), hızlı lipit oksidasyonu önlemektedir (Kozioł, 1992). Ayrıca, kinoa taneleri oldukça yüksek miktarda biyoaktif bileşikler (polifenoller, saponinler, flavonoidler ve fenolik asitler) içermektedir (Doğan ve Karwe, 2003; Paśko ve ark., 2009; Alvarez-Jubete ve ark., 2010; Diaz ve ark., 2013). Kinoanın sahip olduğu bu biyoaktif bileşenlerin, kan kolesterol seviyelerini düşürdüğü, kanser hücrelerinin gelişimini engellediği, toksinleri yok ettiği, immün sistemini güçlendirdiği ve kardiyovasküler hastalıkları önlediği bilimsel olarak ortaya konmuştur (Guzman -Maldonado ve Paredes-Lopez, 1998).

Kinoanın kendine özgü aroması olması ve Türk damak tadına uygunluğu nedeniyle son zamanlarda oldukça dikkat toplamış (Anonim, 2012) ve tarhana formülasyonunda kullanılabileceği öngörülmüştür. Bu çalışma, farklı oranlarda ve \%100 kinoa unu ile yapılan tarhanaların fiziksel, kimyasal, fonksiyonel ve duyusal özelliklerinin belirlenmesi amacıyla gerçekleştirilmiştir.

\section{Materyal ve Metot}

\section{Materyal}

Tarhana üretiminde kullanılan buğday unu (\%10.54 nem, \%0.68 kül, \%10.52 ham protein ve \%1.04 ham yağ) (Tip 550) Konya ilinde faaliyet gösteren bir un fabrikasından, kinoa (\%10.43 nem, \%1.91 kül, \%15.07 ham protein ve \%4.57 ham yağ) istanbul'da faaliyet gösteren bir firmadan, konsantre tam yağlı torba yoğurdu, domates salçası, kuru soğan, kırmızı toz biber, pres yaş maya (Saccharomyces cerevisiae) ve sofra tuzu ise Konya'daki yerel marketlerden temin edilmiştir.

Tarhana üretimi geleneksel yolla gerçekleştirilmiş olup, üretimde kullanılan kinoa örnekleri, laboratuvar tipi çekiçli değirmende (LM 3100, Perten Instruments AB, İsveç) 500 mikron çaplı göz açıklığı bulunan elek kullanılarak öğütülmüştür. Elde edilen kinoa unu, buğday unu ile 6 farklı oranda (\% 0,20,40,60, 80 ve 100) ikame edilerek tarhana üretiminde kullanılmış ve çalışma iki tekerrürlü olarak yürütülmüştür.

\section{Tarhana üretimi}

Tarhana üretiminde buğday unu (\%0-100), kinoa (\%100-0), yoğurt (\%40), domates salçası (\%10), kuru soğan (\%5), yaş maya (\%2.5), kırmızı 
toz biber (\%2), tuz (\%1) ve su ( \%40) kullanılmıştır. Formülasyonda belirtilen malzemeler karıştırıcıda (kMix KMX50, Kenwood, Ingiltere) 5 dakika süre ile yoğurulmuştur. Elde edilen karışımlar, $21 \mathrm{~cm}$ çapındaki plastik kaplara $2 \mathrm{~cm}$ kalınlığında yerleştirilerek $30^{\circ} \mathrm{C}^{\prime}$ de 72 saat süre ile inkübatör içerisinde fermentasyona bırakılmıştır (Bilgiçli ve íbanoğlu, 2007). Fermentasyon işlemi sırasında tarhana hamurları, her on iki saatte bir, bulundukları kap içerisinde karıştırılmıştır. Fermentasyon sonunda; tarhana hamuru örnekleri küçük parçalara (yaklaşık $2 \mathrm{~cm}$ çapında) bölünerek, $55^{\circ} \mathrm{C}^{\prime}$ de 48 saat süre ile kurutma fırınında (Nüve KD-200, Türkiye) kurutulmuştur. Kurutulmuş tarhana örnekleri çekiçli değirmende (LM 3100, Perten Instruments $A B$, İsveç) $500 \mu$ göz açıklığına sahip elek sistemi kullanılarak öğütülmüştür. Öğütülen kuru tarhana örnekleri, ağzı kapalı cam kaplarda oda sıcaklığında muhafaza edilmiştir (Bilgiçli, 2009).

\section{Kimyasal analizler}

Kuru tarhana örneklerinin nem (44-19.01), kül (08-01.01), protein (46-12.01) ve ham yağ (3025.01) içerikleri AACC metotları (AACC, 1999) kullanılarak kuru madde üzerinden belirlenmiştir. Fitik asit değerleri, kolorimetrik metot kullanılarak Haug ve Lantzsch (1983)'e göre belirlenmiştir. Örneklerden, hidroklorik asit çözeltisi ile ekstrakte edilen fitik asit, Demir III çözeltisi ile çöktürülmüş, serum kısmında kalan demir miktarı spektrofotometrik yolla belirlenerek fitik asit miktarı hesaplanmıştır.

Tarhanaların toplam fenolik madde içeriği, Folin-Ciocaltaeu metodu Beta ve ark. (2005)'e göre modifiye edilerek uygulanmıştır. Örnekler (200 mg), asitlendirilmiş metanol $(\mathrm{HCl} / \mathrm{metanol} / \mathrm{su}, 1: 80: 10 \mathrm{~h} / \mathrm{h})$ içerisinde $(4 \mathrm{ml}), 2$ saat süre ile çalkalamalı su banyosunda $\left(24 \pm 1^{\circ} \mathrm{C}\right)$ bekletilmiştir. Daha sonra 3000 rpm'de 10 dakika santrifüjlenerek elde edilen ekstraktların toplam fenolik madde içeriği tespit edilmiştir. Analizde $0.1 \mathrm{ml}$ ekstrakt, $0.5 \mathrm{ml}$ Folin-Ciocaltaeu reaktifi (\%10'luk, h/h, suda) ve $1.5 \mathrm{ml}$ sodyum karbonat çözeltisi (\%20'lik, a/h, suda) deney tüpünde karıştırılarak, $10 \mathrm{ml}$ 'ye saf su ile tamamlanmış ve 2 saat oda sıcaklığında $\left(24 \pm 1^{\circ} \mathrm{C}\right)$ inkübe edilmiştir. Süre sonunda çözeltilerin absorbans değerleri spektrofotometrede (Libra S60, Biochrom, Ingiltere) $760 \mathrm{~nm}$ 'de okunmuş ve sonuçlar gallik asit [mg GAE $(100 \mathrm{~g})^{-1}$ ] cinsinden hesaplanmıştır (Slinkard ve Singleton, 1977).

\section{Renk analizi}

Tarhana örneklerinin renk değerleri otomatik renk tayin cihazı (Konica-Minolta, CR-400, Japonya) kullanılarak ölçülmüştür. Sonuçlar $L^{*}[(0)$ siyah - (100) beyaz], a* [(+) kırmızı - (-) yeşil] ve b* $[(+)$ sarı - (-) mavi] değeri olarak belirlenmiştir (Francis, 1998).

\section{Viskozite analizleri}

$10 \mathrm{~g}$ kuru tarhana örneği, $100 \mathrm{ml}$ saf su ile karıştırılarak, 10 dakika süreyle karıştırılarak pişirilmiştir. Tarhana çorbalarının viskozite ölçümleri, $60^{\circ} \mathrm{C}$ sıcaklıkta $100 \mathrm{dev} \mathrm{dk}^{-1}$ dönme hızında, rotasyonel viskozimetre (Brookfield RTV, Spindle no: 5) ile gerçekleştirilmiştir (Bilgiçli, 2009).

\section{Duyusal analizler}

Tarhana örnekleri; Bilgiçli (2009)'ye göre pişirilerek, yaşları 20-55 arasında değişen ve konu ile ilgili aynı koşullar altında kısa bir eğitime tabi tutulan, 10 kişilik panelist grubu tarafından duyusal analize tabi tutulmuştur. Tarhana örnekleri panelistlere $45-50^{\circ} \mathrm{C}^{\prime}$ de çorba olarak sunulmuştur. 1-5 arasında bir skala (1-kötü, 3kabul edilebilir ve 5-oldukça iyi) kullanılarak renk, tat-koku, kıvam, ekşilik, kumluluk ve genel kabul edilebilirlik bakımından değerlendirilmeleri istenmiştir.

\section{Istatistiki analizler}

Denemeler 2 tekerrürlü olarak yürütülmüştür. Araştırma sonucunda elde edilen veriler varyans analizine tabi tutularak, ortalamaları arasındaki fark $P \leq 0.05$ anlamlılık düzeyinde Duncan testi yapılarak belirlenmiştir. Analiz sonuçlarının istatistiksel değerlendirmesi SPSS 17.0.1 paket programı (SPSS Inc., Chicago, Illinois, US) kullanılarak yapılmıştır.

\section{Araştırma Bulguları ve Tartışma}

Tarhana yapımında kullanılan buğday ununun renk $L^{*}$ (parlaklık), a* (kırmızılık) ve $b^{*}$ (sarılık) değerleri sırasıyla 93.64, -1.39, 11.04; kinoa ununun ise $88.01,-0.27,13.24$ olarak ölçülmüştür. Buğday ununun \%10.54 nem, \%0.68 kül, \%10.52 ham protein ve \%1.04 ham yağ içeriğine, kinoa ununun ise \%10.43 nem, \%1.91 kül, \%15.07 ham protein \%4.57 ham yağ içeriğine sahip olduğu belirlenmiştir. Bu sonuçlara göre kinoa ununun, buğday ununa göre; daha yüksek oranda ham protein, ham yağ ve kül içerdiği ve daha koyu, 
kırmızı ve sarı renkli olduğu görülmüştür. Kinoa unu ikamesiyle üretilen tarhana örneklerinin $L^{*}$, $a * v e b^{*}$ değerlerine Çizelge 1 'de verilmiştir. Tarhanaların; "L*" değerleri 73.09 - 79.39, “a*” değerleri 6.96 - 8.35 ve " $b$ *" değerleri ise 28.28 ile 34.57 arasında değişim göstermektedir. Elde edilen bu sonuçlara göre; kinoa unu ikamesiyle üretilen tarhana örneklerinin $L^{*}, a^{*}$ ve $b^{*}$ değerlerinin azaldığı tespit edilmiştir. Renk değerlerindeki bu değişimin, hammadde renk değerlerinden kaynaklandığı düşünülmektedir. En yüksek parlaklık, kırmızılık ve sarılık değerleri \%100 buğday unu ile üretilen kontrol grubu örneklerde tespit edilmiştir. \%20 kinoa unu ikame oranına kadar tarhana örneklerinin renk özellikleri kontrol örneğine yakın değerler gösterdiği belirlenmiştir. Genel olarak, kinoa unu ikame oranlarındaki artış, son ürün renginde değişimlere sebep olmuş, daha mat ve koyu renkli ürünlerin ortaya çıkmasına neden olmuştur. Bu durum, hammaddenin renk yoğunluğuna, esmerleşme reaksiyonuna ve yüksek fitik asit içeriğine bağlı olabilir. Bilgiçli (2009), tarhana fermentasyonu sırasında fitik asidin parçalandığını, tarhanın serbest mineral içeriğinin arttığını ve bu serbest minerallerin de bazı enzimatik olmayan esmerleşme reaksiyonlarını katalize ettiğini bildirmiştir. Kinoa unu, pirinç unu ve patates nişastasının 3 farklı (\%40:30:30, \%50:25:25 ve $\% 60: 20: 20)$ oranda kullanılarak üretildiği glutensiz tarhana çalışmasında; kinoa oranındaki artışa bağlı olarak $L^{*}$ (parlaklık) değerlerinin 77.74 'den 74.92'ye, b* (sarılık) değerlerinin ise $36.52^{\prime}$ den 32.29'a düştüğünü tespit etmiştir (Demir, 2014). Iglesias-Puig ve ark. (2015), çalışmalarında \%25 ve $\% 50$ oranında kinoa unu kullanarak ürettikleri ekmek $L^{*}$ renk değerlerini sırasıyla 52.4 ve 51.5 olarak, kontrol örneğinin $L^{*}$ renk değeri 66.3 olarak belirlemişlerdir. Lorusso ve ark. (2017) \%20 onanında kinoa unu kullanarak ürettikleri makarnanın $L^{*}, a^{*}$ ve $b^{*}$ renk değerlerini sırasıyla; $59.29,-1.14$ ve 16.48 olarak bildirmişlerdir. Aynı çalışmada buğday unundan üretilen makarnaların $L^{*}, a^{*}$ ve $b^{*}$ değerleri ise sırasıyla $66.10,-3.18$ ve 19.34 olarak belirlenmiştir. Atef ve ark. (2014) çalışmalarında kinoa ununu farklı oranlarda bisküvi yapımında kullanmışlar ve \%100 buğday unundan üretilen bisküvi örneklerinin $L^{*}$ ve $b^{*}$ renk özelliklerini sırasıyla, 58.40 ve 21.34 olarak; \%100 kinoa unundan üretilmiş bisküvi örneklerinin ise sırasıyla 53.42 ve 14.60 olarak bulmuşlardır. Yukarıda verilen literatür araştırmalarına göre, kinoa unu kullanımı, örneklerin renk özellikleri üzerine benzer etki göstermektedir. Turkut ve ark. (2016) farklı oranlarda kinoa, karabuğday, pirinç ve patates kullanarak ürettikleri glutensiz ekmeklerde kinoa unu miktarının artışı ile nem içeriklerinin azaldığını bildirmişlerdir. Alvarez-Jubete ve ark. (2010) \%50 kinoa unu kullanarak elde ettikleri glutensiz ekmeklerde benzer sonuçlar gözlemlemişlerdir.

Tarhana örneklerine ait en yüksek kül değerleri, \%100 kinoa unu ile üretilen tarhana örneklerinden (\%4.22) elde edilmiş olup, en düşük kül miktarı ise, \%100 (\%2.27) buğday unu ile üretilenkontrol gurubu tarhana örneklerinde tespit edilmiştir. Demir (2014) yapmış olduğu glutensiz kinoa tarhana denemelerinde, kinoa oranı arttıkça kül oranlarının \%3.01'den \%3.41'e arttığını tespit etmiştir. Yapılan bir başka çalışmada da, \%25 ve \%50 oranlarında kinoa unu kullanılarak elde edilen ekmek örneklerinin kül miktarları sırasıyla \%1.82 ve \%2.19 olarak belirlenmiş olup, kinoa unun artan oranlarda kullanılmasıyla ekmek örneklerinin kontrol göre (\%1.42) kül içeriğinin arttığı tespit edilmiştir (Iglesias-Puig ve ark., 2015). Glutensiz ekmek üzerine yapılan bir diğer çalışmada; kinoa içermeyen örneklerin kül içeriği kontrol örneklerde \%1.68 olarak, \%50 oranında kinoa içerenler ise \%2.06 olarak tespit edilmiştir (Turkut ve ark., 2016).

Üretilen tarhanaların ham yağ oranları \%2.406.18 arasında değişim göstermiştir. En yüksek ham yağ içeriği \%6.18 ile \%100 kinoa ile üretilen tarhana örneklerinden elde edilmişken, en düşük ham yağ değerleri (\%2.40) ise kontrol grubu örneklerinden elde edilmiştir. Kinoa kullanım oranının artması ile tarhana örneklerinin ham yağ miktarında artış görülmüştür. Kinoanın yağ içeriğinin yüksek olması ve doğal antioksidan özellikli vitamin E'yi yüksek miktarda bulundurması (Kozioł, 1992), kullanıldıkları ürünlerin besinsel özelliklerini olumlu yönde etkilediği düşünülmektedir. Rizzello ve ark. (2016), kinoa unu ve fermente kinoa ununun kimyasal bileşenlerini inceledikleri çalışmalarında, kinoa ununun ham yağ içeriğinin \%6'dan fermantasyon işlemi ile \%6.3 yükseldiğini tespit etmişlerdir. Yapılan başka bir çalışmada \%20 oranında fermente kinoa ununun makarna üretimde kullanılması sonucu örneklerin yağ içeriği \%2.62 olarak belirlenmiş olup, kontrol örneği yağ içeriğinin ise \%0.60 olduğu görülmüştür (Lorusso ve ark., 2017). 
Tarhana örneklerinin ortalama ham protein değerlerinin \%14.58 ile 19.03 arasında değişim gösterdiği belirlenmiştir (Çizelge 1). Tarhana formülasyonunda kinoa unu miktarındaki artış, son ürünlerin ham protein değerlerini yükseltmiştir. Demir (2014) kinoa unu kullanmak suretiyle yapmış olduğu glutensiz tarhana üretimlerinde, tarhanaların ham protein içeriklerinin \%16.26 ile \%16.99 arasında değişim gösterdiğini rapor etmiştir. Çevik (2016) farklı oranlarda (\% 0, 10, 20, 30 ve 40), kinoa unu içeren tarhanaların ortalama ham protein değerlerinin \%12.86 ile 13.33 arasında değiştiğini bildirmiştir. (Rizzello ve ark., 2016), \%12.5 oranında kinoa unu kullanarak elde ettikleri ekmek örneklerinin protein içeriğini \%11.1 olarak belirlerken, buğday unundan elde edilmiş olan kontrol örneğinin protein içeriğini \%10.2 olduğunu bildirmişlerdir.

Hububat ürünlerinde doğal bir bileşen olarak bulunan fitik asit, insan beslenmesinde gerekli olan $\mathrm{Ca}, \mathrm{Fe}, \mathrm{Zn}, \mathrm{Mg}$ ve $\mathrm{Cu}$ gibi minerallerle şelat oluşturarak bunların biyoyararlılığını düşürmektedir. Bu nedenle fitik asit besleyici kaliteyi olumsuz yönde etkileyen anti-besinsel bir öğedir. Ayrıca fitik asidin minerallerle birleşmesiyle oluşan fitatlar, fitat-protein kompleksleri oluşturarak protein emilimini de olumsuz yönde etkilemektedir (Bilgiçli, 2002; Özkaya, 2004). Tahıl tanelerinin kepekli fraksiyonları ve ruşeym tabakaları fitik asit bakımından zengindir ve fitik asit genelde embriyoda konumlanmıştır (Hoseney, 1994). Kinoa tohumunda ise embriyonun yanı sıra dış tabakalarda da bulunmaktadır (ValenciaChamorro, 2003; Jancurová ve ark., 2009). Dolayısıyla; kinoa unu buğday ununa göre, daha yüksek fitik asit içeriğine sahiptir. Bu çalışmada, üretilen tarhana örneklerinin fitik asit miktarlarının 26.16 ile $100.46 \mathrm{mg}(100 \mathrm{gg})^{-1}$ arasında değiştiği tespit edilmiştir (Çizelge 1). Tarhana üretiminde kullanılan buğday ve kinoa ununun fitik asit miktarları sırasıyla 371 ve $934 \mathrm{mg}$ $(100 \mathrm{~g})^{-1}$ olarak belirlenmiştir. Sonuç olarak tarhana üretiminde kinoa ununun kullanılması ile örneklerin, fitik asit içeriğini belirgin bir şekilde arttırmıştır. Dolayısıyla artan oranlardaki kinoa unu ikamesinin tarhanaların besinsel kalitesini olumsuz etkilediği düşünülebilir, ancak fitik asidin antioksidan özelliği göz önüne alındığında tarhana örneklerinin fonksiyonelliğinin arttığı da ifade edilebilir.

Çizelge 1. Tarhanaların fiziksel, kimyasal ve besinsel özelliklerine kinoa ununun etkisi ${ }^{1}$

Table 1. Influence of quinoa flour on the physical, chemical and nutritional properties of tarhana ${ }^{1}$

\begin{tabular}{|c|c|c|c|c|c|c|}
\hline Örnek ${ }^{2}$ & Kontrol & \%20 KU & \%40 KU & $\% 60 \mathrm{KU}$ & $\% 80 \mathrm{KU}$ & $\% 100 \mathrm{KU}$ \\
\hline $\begin{array}{l}\text { Nem (\%) } \\
\text { Moisture }\end{array}$ & $\begin{array}{l}4.76^{\mathrm{a}} \\
\pm 0.07 \\
\end{array}$ & $\begin{array}{l}4.29^{\mathrm{ab}} \\
\pm 0.36 \\
\end{array}$ & $\begin{array}{r}4.76^{\mathrm{a}} \\
\pm 0.27 \\
\end{array}$ & $\begin{array}{l}4.59^{\mathrm{ab}} \\
\pm 0.25 \\
\end{array}$ & $\begin{array}{l}4.05^{b} \\
\pm 0.01 \\
\end{array}$ & $\begin{array}{l}4.59^{\mathrm{a}} \\
\pm 0.10 \\
\end{array}$ \\
\hline $\begin{array}{l}\text { Kül (\%) } \\
\text { Ash } \\
\end{array}$ & $\begin{array}{l}2.27^{f} \\
\pm 0.04 \\
\end{array}$ & $\begin{array}{l}2.93^{\mathrm{e}} \\
\pm 0.01 \\
\end{array}$ & $\begin{array}{l}3.36^{\mathrm{d}} \\
\pm 0.03 \\
\end{array}$ & $\begin{array}{l}3.80^{c} \\
\pm 0.01 \\
\end{array}$ & $\begin{array}{l}3.97^{b} \\
\pm 0.01 \\
\end{array}$ & $\begin{array}{l}4.22^{\mathrm{a}} \\
\pm 0.04 \\
\end{array}$ \\
\hline $\begin{array}{l}\text { Ham Yağ (\%) } \\
\text { Crude Fat }\end{array}$ & $\begin{array}{l}2.40^{\mathrm{e}} \\
\pm 0.25\end{array}$ & $\begin{array}{l}4.02^{\mathrm{d}} \\
\pm 0.01\end{array}$ & $\begin{array}{l}4.92^{\mathrm{c}} \\
\pm 0.11 \\
\end{array}$ & $\begin{array}{l}5.52^{b} \\
\pm 0.01 \\
\end{array}$ & $\begin{array}{l}5.84^{\mathrm{ab}} \\
\pm 0.06 \\
\end{array}$ & $\begin{array}{l}6.18^{\mathrm{a}} \\
\pm 0.06 \\
\end{array}$ \\
\hline $\begin{array}{l}\text { Ham Protein (\%) } \\
\text { Crude Protein }\end{array}$ & $\begin{array}{l}14.58^{\mathrm{e}} \\
\pm 0.31\end{array}$ & $\begin{array}{l}15.46^{\mathrm{d}} \\
\pm 0.20\end{array}$ & $\begin{array}{l}16.50^{c} \\
\pm 0.50\end{array}$ & $\begin{array}{l}17.26^{b} \\
\pm 0.06\end{array}$ & $\begin{array}{l}18.28^{\mathrm{a}} \\
\pm 0.23\end{array}$ & $\begin{array}{l}19.03^{\mathrm{a}} \\
\pm 0.12\end{array}$ \\
\hline$L^{*}$ & $\begin{array}{l}79.39^{\mathrm{a}} \\
\pm 0.73\end{array}$ & $\begin{array}{l}76.19^{\mathrm{ab}} \\
\pm 0.56\end{array}$ & $\begin{array}{c}75.74^{b c} \\
\pm 0.81\end{array}$ & $\begin{array}{l}73.09^{d} \\
\pm 0.79\end{array}$ & $\begin{array}{l}73.48^{\mathrm{cd}} \\
\pm 0.60\end{array}$ & $\begin{array}{c}75.18^{\text {cd }} \\
\pm 1.79\end{array}$ \\
\hline$a^{*}$ & $\begin{array}{l}8.35^{\mathrm{a}} \\
\pm 0.45 \\
\end{array}$ & $\begin{array}{l}8.33^{\mathrm{a}} \\
\pm 0.02 \\
\end{array}$ & $\begin{array}{l}7.33^{b c} \\
\pm 0.31\end{array}$ & $\begin{array}{l}7.96^{\mathrm{ab}} \\
\pm 0.35\end{array}$ & $\begin{array}{l}7.57^{\mathrm{abc}} \\
\pm 0.01\end{array}$ & $\begin{array}{l}6.96^{c} \\
\pm 0.31\end{array}$ \\
\hline$b^{*}$ & $\begin{array}{l}34.57^{\mathrm{a}} \\
\pm 0.63\end{array}$ & $\begin{array}{l}33.54^{\mathrm{a}} \\
\pm 0.09\end{array}$ & $\begin{array}{l}30.82^{b} \\
\pm 0.39\end{array}$ & $\begin{array}{l}30.82^{b} \\
\pm 0.65\end{array}$ & $\begin{array}{l}29.36^{c} \\
\pm 0.06\end{array}$ & $\begin{array}{l}28.28^{C} \\
\pm 0.27\end{array}$ \\
\hline $\begin{array}{l}\left.\text { Fitik Asit [mg }(100 \mathrm{~g})^{-1}\right] \\
\text { Phytic acid }\end{array}$ & $\begin{array}{l}26.16^{\dagger} \\
\pm 1.12\end{array}$ & $\begin{array}{l}39.61^{e} \\
\pm 0.93 \\
\end{array}$ & $\begin{array}{l}54.47^{d} \\
\pm 1.10 \\
\end{array}$ & $\begin{array}{l}71.17^{c} \\
\pm 0.74 \\
\end{array}$ & $\begin{array}{l}86.67^{b} \\
\pm 0.98 \\
\end{array}$ & $\begin{array}{c}100.46^{\mathrm{a}} \\
\pm 1.09 \\
\end{array}$ \\
\hline $\begin{array}{l}\text { Toplam Fenolik Madde } \\
{\left[\mathrm{mg} \text { GAE }(100 \mathrm{~g})^{-1}\right]} \\
\text { Total Phenolic Content }\end{array}$ & $\begin{array}{c}645.20^{\mathrm{e}} \\
\pm 1.25\end{array}$ & $\begin{array}{r}1096.45^{d} \\
\pm 15.04\end{array}$ & $\begin{array}{l}1316.35^{c} \\
\pm 125.37\end{array}$ & $\begin{array}{c}1494.80^{\mathrm{bc}} \\
\pm 53.49\end{array}$ & $\begin{array}{l}1594.10^{\mathrm{ab}} \\
\pm 100.30\end{array}$ & $\begin{array}{r}1751.60^{a} \\
\pm 46.39\end{array}$ \\
\hline $\begin{array}{l}\text { Viskozite }(\mathrm{cP})^{3} \\
\text { Viscosity }\end{array}$ & $\begin{array}{l}138.26^{\mathrm{a}} \\
\pm 16.43\end{array}$ & $\begin{array}{l}119.85^{\mathrm{a}} \\
\pm 16.07 \\
\end{array}$ & $\begin{array}{r}114.96^{\mathrm{a}} \\
\pm 9.61 \\
\end{array}$ & $\begin{array}{l}67.98^{b} \\
\pm 10.30 \\
\end{array}$ & $\begin{array}{l}49.98^{b} \\
\pm 2.27\end{array}$ & $\begin{array}{l}42.04^{b} \\
\pm 5.14\end{array}$ \\
\hline
\end{tabular}

${ }^{1}$ Aynı satırdaki aynı harfle işaretlenmiş ortalamalar istatistiki olarak birbirinden farklı değildir $(P \leq 0.05)$. Nem dışındaki kimyasal özellikler kuru madde üzerinden verilmiştir.; ${ }^{2} \mathrm{KU}$ : Kinoa unu ; ${ }^{3}$ Tarhana çorbasında.

${ }^{1}$ Means with same letter within column are not significantly different $(P \leq 0.05)$. Chemical properties except moisture are based on dry matter.; ${ }^{2} \mathrm{KU}$ : Quinoa flour; ${ }^{3}$ Tarhana soup. 
Fenolik bileşenler birçok bitkide, tahıllarda ve diğer hububat ürünlerinde önemli miktarda bulunan, antioksidan aktiviteye sahip bileşiklerdir. Tahıl tanesindeki fenolikler, özellikle de tanelerin dış kısımlarına yakın tabakalarında yoğun bir şekilde bulunmaktayken, kinoa tanesinin bütün tabakalarında yakın değerlerde yer almaktadır (Beta ve ark., 2005). Bu çalışmada, tarhana örneklerinin toplam fenolik madde içeriği, 645.20 ile $1751.60 \mathrm{mg} \mathrm{GAE} 100 \mathrm{~g}^{-1}$ arasında değişim göstermiştir. Elde edilen bu verilere göre, tarhana üretiminde kullanılan kinoa unu oranındaki artışa bağlı olarak, toplam fenolik madde miktarlarında artmıştır.

Tarhanada viskoz, kıvamlı bir yapının oluşması nişastanın kıvam artırıcı özelliğinden kaynaklanmaktadır. Nişastanın yanı sıra yağ ve proteinlerin de viskoziteyi etkiledikleri bildirilmiştir (Erkan, 2004; Durmuş, 2015). Tarhana örneklerinin viskozite değerleri $42.04 \mathrm{cP}$ ile $138.26 \mathrm{cP}$ arasında değişim göstermiştir (Çizelge 1). Gökmen (2009) buğday unlu tarhana örneklerinde yaptığı ölçümlerde viskoziteyi 102 cP olarak bildirilmiştir. İbanoğlu ve ark. (1998) viskozite üzerine yaptığı çalışmada tarhanaların $40^{\circ} \mathrm{C}^{\prime}$ da 2 saat boyunca $0.2 \mathrm{~N}$ ve $0.6 \mathrm{~N} \mathrm{HCl}$ çözeltisinde bekletmişler ve viskoziteyi sırasıyla 46 cP ve 15 cP olarak saptanmışlardır. Çizelge 1'e göre; en yüksek viskozite değerleri kontrol grubunda elde edilmişken, en düşük değerler ise \%100 kinoa unu ikameli tarhanalarda elde edilmiştir. İkame oranlarındaki artış sayısal olarak viskozite değerlerini düşürürken, $\% 40$ oranına kadar kinoa unu ikamesi istatistiki olarak kontrolden farksız $(P \leq 0.05)$ viskozite değerleri vermiştir. Aynı şekilde \% 60, \% 80 ve $\% 100$ kinoa ikame oranları da, istatistiksel olarak tarhana viskozitesinde anlamlı bir azalma gözlenmemiştir. Bu sonuçlara göre; artan oranlarda kinoa ununun kullanılması, viskozitede belirgin bir düşüşe sebep olmuştur. Bunun muhtemel sebebi, gluten ve nişastanın seyrelmesidir. Her ne kadar kinoa da nişasta bulunsa da buğday ile aynı yapı değildir ve viskoziteye düşüş olarak yansımıştır.

Tarhana örneklerinin duyusal özelliklerine ait sonuçlar Çizelge 2' te verilmiştir. Kinoa ilavesi ile tarhana çorbası örneklerinin renk açısından daha fazla beğeni kazanmıştır. \%100 kinoa unu kullanımının, tat, koku, kumluluk ve genel beğeni puanlama değerleri üzerinde azalma meydana getirdiği belirlenmiştir. Genel beğeni değerlendirmelerinde en yüksek puan \%20 kinoa unu ikamesinin verdiği, ikame oranı arttıkça bu puanlama değerlerinin azaldığı, fakat istatistiki açıdan önemli seviyede $(P \leq 0.05) \quad$ olmadığı belirlenmiştir. \%100 kinoa unu kullanılan tarhana örnekleri ise, renk hariç diğer tüm duyusal değerlendirme kriterlerinde daha düşük puanlama değerleri belirlenmiştir. Baker ve ark. (2013) çalışmalarında pirinç unundan ürettikleri mufinlerde $\% 20$ ve $\% 50$ oranlarında kinoa unu kullanarak duyusal özelliklerini \%100 pirinç unundan üretilmiş örneklerle karşılaştırmışlardır. Yapılan karşılaştırmada \%50 oranında pirinç ununa ikame olarak kinoa unu kullanılan örneklerin, panelistler tarafından daha çok beğenildiği bildirilmiştir.

Çizelge 2. Tarhana çorbalarının duyusal özelliklerine kinoa ununun etkisi ${ }^{1}$

Table 2. Influence of quinoa flour on the sensorial properties of tarhana soups ${ }^{1}$

\begin{tabular}{|c|c|c|c|c|c|c|c|}
\hline Örnek ${ }^{2}$ & $\begin{array}{l}\text { Renk } \\
\text { Colour }\end{array}$ & $\begin{array}{c}\text { Tat } \\
\text { Taste }\end{array}$ & $\begin{array}{l}\text { Koku } \\
\text { Odour }\end{array}$ & $\begin{array}{c}\text { Kıvam } \\
\text { Consistency }\end{array}$ & $\begin{array}{c}\text { Ekşilik } \\
\text { Sourness }\end{array}$ & $\begin{array}{l}\text { Kumluluk } \\
\text { Sandiness }\end{array}$ & $\begin{array}{c}\text { Genel Beğeni } \\
\text { Overall } \\
\text { Acceptability }\end{array}$ \\
\hline \multirow{2}{*}{ Kontrol } & $3.75^{b}$ & $3.88^{\mathrm{ab}}$ & $4.25^{\mathrm{ab}}$ & $4.25^{a}$ & $4.38^{a}$ & $4.88^{\mathrm{a}}$ & $4.25^{\mathrm{ab}}$ \\
\hline & \pm 0.27 & \pm 0.67 & \pm 0.27 & \pm 0.71 & \pm 1.34 & \pm 0.45 & \pm 0.71 \\
\hline \multirow{2}{*}{$\% 20 K U$} & $4.75^{a}$ & $4.50^{\mathrm{a}}$ & $4.38^{\mathrm{ab}}$ & $4.38^{a}$ & $4.50^{\mathrm{a}}$ & $4.38^{\mathrm{ab}}$ & $4.50^{\mathrm{a}}$ \\
\hline & \pm 0.55 & \pm 1.41 & \pm 0.45 & \pm 0.89 & \pm 1.27 & \pm 0.57 & \pm 0.84 \\
\hline \multirow{2}{*}{ \%40KU } & $4.63^{a b}$ & $3.75^{\mathrm{ab}}$ & $4.50^{a}$ & $4.38^{a}$ & $3.88^{\mathrm{a}}$ & $4.25^{\mathrm{ab}}$ & $4.13^{\mathrm{ab}}$ \\
\hline & \pm 0.71 & \pm 0.89 & \pm 0.42 & \pm 0.74 & \pm 1.00 & \pm 0.45 & \pm 0.65 \\
\hline \multirow{2}{*}{$\% 60 K U$} & $4.75^{a}$ & $4.00^{\mathrm{ab}}$ & $4.25^{\mathrm{ab}}$ & $4.13^{a}$ & $4.00^{a}$ & $3.88^{\mathrm{ab}}$ & $3.75^{\mathrm{ab}}$ \\
\hline & \pm 0.55 & \pm 0.96 & \pm 0.61 & \pm 0.55 & \pm 0.96 & \pm 0.55 & \pm 0.55 \\
\hline \multirow{2}{*}{ \%80KU } & $4.50^{\mathrm{ab}}$ & $3.50^{\mathrm{ab}}$ & $4.00^{\mathrm{ab}}$ & $4.00^{a}$ & $3.88^{a}$ & $3.75^{\text {ba }}$ & $3.50^{\mathrm{ab}}$ \\
\hline & \pm 0.42 & \pm 0.76 & \pm 0.45 & \pm 0.84 & \pm 1.00 & \pm 0.57 & \pm 0.42 \\
\hline \multirow{2}{*}{$\% 100 \mathrm{KU}$} & $4.38^{\mathrm{ab}}$ & $3.13^{b}$ & $3.88^{b}$ & $3.63^{\mathrm{a}}$ & $3.88^{\mathrm{a}}$ & $3.75^{b}$ & $3.38^{b}$ \\
\hline & \pm 0.45 & \pm 0.55 & \pm 0.45 & \pm 1.12 & \pm 1.00 & \pm 0.57 & \pm 0.45 \\
\hline
\end{tabular}

\footnotetext{
${ }^{1}$ Aynı sütundaki aynı harfle işaretlenmiş ortalamalar istatistiki olarak birbirinden farklı değildir $(P \leq 0.05)$.; ${ }^{2} \mathrm{KU}$ : Kinoa unu.

${ }^{1}$ Means with same letter within column are not significantly different $(P \leq 0.05) . ;{ }^{2} K U$ : Quinoa flour.
} 


\section{Sonuçlar}

$\mathrm{Bu}$ çalışmada, buğday unu yerine belirli oranlarda (\%0, 20, 40, 60, 80 ve 100) kinoa unu ikamesi ve hazırlanan paçalların tarhana üretiminde kullanılma imkanları incelenmiş olup, üretilen bu tarhanaların bazı fiziksel, kimyasal, besinsel ve duyusal özelliklerindeki değişimler araştırılmıştır. Sonuç olarak; kinoa unu ikamesiyle üretilen tarhananın örneklerinin genel olarak $L^{*}$, $a^{*}$ ve $b^{*}$ değerlerinin azaldığı tespit edilmiştir. Elde edilen kimyasal analiz sonuçlarına göre, tarhana formülasyonunda kinoa unu miktarında artışa gidilmesi ile, son ürün olan tarhanaların kül, ham protein, ham yağ, fitik asit ve toplam fenolik madde içeriklerinin arttığı tespit edilmiştir. Duyusal analiz sonuçlarına göre de; tarhana üretiminde kinoa unu kullanımı ve kullanılan oranlarda artışlara gidilmesinin olumsuz bir etkiye sahip olmadığı, \%100 kinoa unu ile ikame edilenler hariç, kinoa ikamesi ile tarhanaların daha beğenilir hale gelebileceği belirlenmiştir.

Elde edilen bu veriler ışığında, toplumun her kesimi tarafından her öğünde sevilerek tüketilen tarhana ürününde, rafine buğday unlarının yerine, besinsel açıdan üstünlüğü ispatlanan kinoa unlarının tercih edilebileceği kanısına varılmıştır.

\section{Ekler}

Bu çalışma Necmettin Erbakan Üniversitesi BAP Koordinasyon Birimi (Proje No: 151219013) tarafından desteklenmiştir.

\section{Kaynaklar}

AACC, (1999). Approved Methods of the American Association of Cereal Chemistry (11th ed.). St Paul, Minnesota.

Alvarez-Jubete, L., Arendt, E.K. \& Gallagher, E. (2009). Nutritive value and chemical composition of pseudocereals as gluten-free ingredients. Int J Food Sci Nutr, 60 (4), 240-257.

Alvarez-Jubete, L., Arendt, E. K. \& Gallagher, E. (2010). Nutritive value of pseudocereals and their increasing use as functional gluten-free ingredients. Trends in Food Science \& Technology, 21 (2), 106-113.

Anonim (2012). Kinoa Nedir \& Faydaları Nelerdir? https://www.neoldu.com/kinoa-nedir-faydalarinelerdir-16229h.htm. (Erişim tarihi; 01.11.2018).

Atef, A., Abou-Zaid, I., El-Faham, S. Y., Wafaa, H., \& Emam, H. (2014). Use of Quinoa Meal to Produce Bakery Products to Celiac and Autism Stuffs. International Journal of Science and Research, 3(9), 1344-1354.

Baker, M. G., Hudson, H., Flores, L., Bhaduri, S., Ghatak, R. \& Navder, K.P. (2013). Physical, Textural and Sensory
Properties of Gluten-Free Muffins Prepared Using Quinoa Flour as a Replacement for Rice Flour. Journal of the Academy of Nutrition and Dietetics, 113(9), A60.

Beta, T., Nam, S., Dexter, J.E. \& Sapirstein, H.D. (2005). Phenolic content and antioxidant activity of pearled wheat and roller-milled fractions. Cereal Chemistry, 82(4), 390-393.

Bilgiçli, N. (2002). Fitik asitin beslenme açısından önemi ve fitik asit miktarı düşürülmüş gıda üretim metotları. Selçuk Tarım Bilimleri Dergisi, 16 (30), 79-83.

Bilgiçli, N. (2009). Effect of buckwheat flour on chemical and functional properties of tarhana. LWT-Food Science and Technology, 42 (2), 514-518.

Bilgiçli, N. \& ibanoğlu, Ş. (2007). Effect of wheat germ and wheat bran on the fermentation activity, phytic acid content and colour of tarhana, a wheat flour-yoghurt mixture. Journal of Food Engineering, 78(2), 681-686.

Çevik, A. (2016). Tarhananın besinsel zenginleştirilmesinde kinoa, karabuğday ve lüpen unlarının kullanımı. Yüksek Lisans Tezi, Necmettin Erbakan Üniversitesi, Fen Bilimleri Enstitüsü Gıda Mühendisliği Anabilim Dalı, Konya, 113s.

Daglioğlu, O. (2000). Tarhana as a traditional Turkish fermented cereal food. Its recipe, production and composition. Food/Nahrung, 44(2), 85-88.

Demir, M.K. (2014). Use of quinoa flour in the production of gluten-free tarhana. Food Science and Technology Research, 20(5), 1087-1092.

Doğan, H. \& Karwe, M.V. (2003). Physicochemical properties of quinoa extrudates. Food Science and Technology International, 9(2), 101-114.

Durmuş, Y. (2015). Glutensiz tarhana üretiminde hidrokolloid kullanımının kalite üzerine etkisi. Yüksek Lisans Tezi, Ordu Üniversitesi, Fen Bilimleri Enstitüsü, Gıda Mühendisliği Anabilim Dalı, Ordu, 120s.

Erkan, H. (2004). Farklı tahıl unları kullanılarak üretilen tarhana örneklerinin kimyasal, fonksiyonel ve duyusal özelliklerinin araştırılması. Doktora Tezi, Hacettepe Üniversitesi, Fen Bilimleri Enstitüsü, Gıda Mühendisliği Anabilim Dalı, Ankara, 108s.

Francis, F.J. (1998). Colour Analysis, pp. 599-612. In: S. S. Nielsen (Ed.), Food analysis Aspen Publishers, Gaithersnurg, USA.

Gökmen, S. (2009). Çiğ, pişmiş ve kurutulmuş ayva katkısının tarhana üzerine olan etkisi. Yüksek Lisans Tezi, Afyon Kocatepe Üniversitesi, Fen Bilimleri Enstitüsü, Gıda Mühendisliği Anabilim Dalı, Afyonkarahisar, 81s.

Guzmán-Maldonado, S.H. \& Paredes-Lopez, O. (1998). Functional products of plants indigenous to Latin America: amaranth, quinoa, common beans, and botanicals. Functional foods. Biochemical and processing aspects, 293-328.

Haug, W. \& Lantzsch, H.J. (1983). Sensitive method for the rapid determination of phytate in cereals and cereal products. Journal of the Science of Food and Agriculture, 34(12), 1423-1426.

Hoseney, R. C. (1994). Principles of Cereal Science and Technology. 2nd ed., AACC International, Inc., St Paul, MN.

Ibanogalu, S., Ibanogalu, E. \& Ainsworth, P. (1998). Effect of dilute acid hydrolysis on the cooked viscosity of tarhana, a traditional Turkish cereal soup. 
International journal of food sciences and nutrition, 49(6), 463-466.

Ibanoğlu, Ş., ibanoğlu, E. \& Ainsworth, P. (1999). Effect of different ingredients on the fermentation activity in tarhana. Food Chemistry, 64(1), 103-106.

ibanoğlu, Ş. \& Maskan, M. (2002). Effect of cooking on the drying behaviour of tarhana dough, a wheat flouryoghurt mixture. Journal of Food Engineering, 54(2), 119-123.

Iglesias-Puig, E., Monedero, V. \& Haros, M. (2015). Bread with whole quinoa flour and bifidobacterial phytases increases dietary mineral intake and bioavailability. LWT-Food Science and Technology, 60(1), 71-77.

Jancurová, M., Minarovicová, L. \& Dandar, A. (2009). Quinoa-a review. Czech Journal of Food Sciences, 27(2), 71-79.,

Kaya, í. Ç. (2010). Akdeniz bölgesinde damla sistemiyle tatli ve tuzlu su kullanilarak uygulanan farkli sulama stratejilerinin quinoa bitkisinin verimiyle toprakta tuz birikimine etkileri ve saltmed modelinin test edilmesi. Doktora Tezi, Çukurova Üniversitesi, Fen Bilimleri Enstitüsü, Tarımsal Yapılar ve Sulama Anabilim Dalı, Adana, 227s.

Koyun, S. (2013). Güvenli gida: quinoa (Chenopodium quinoa Willd.). Mesleki Bilimler Dergisi, 2(2), 85-88.

Kozioł, M.J. (1992). Chemical composition and nutritional evaluation of quinoa (Chenopodium quinoa Willd.). Journal of Food Composition and Analysis, 5(1), 35-68.

Lorusso, A., Verni, M., Montemurro, M., Coda, R., Gobbetti, M. \& Rizzello, C.G. (2017). Use of fermented quinoa flour for pasta making and evaluation of the technological and nutritional features. LWT-Food Science and Technology, 78, 215-221.

Ng, S. C., Anderson, A., Coker, J. \& Ondrus, M. (2007). Characterization of lipid oxidation products in quinoa (Chenopodium quinoa). Food Chemistry, 101(1), 185192.

Özkaya, B. (2004). The effect of variety and extraction on phytic acid content of bread. Ankara University, Scientific Research Projects, Project, (2002-07), 11064.
Park, S. H. \& Morita, N. (2007). Changes of bound lipids and composition of fatty acids in germination of quinoa seeds. Food science and technology research, 10(3), 303-306.

Paśko, P., Bartoń, H., Zagrodzki, P., Gorinstein, S., Fołta, M. \& Zachwieja, Z. (2009). Anthocyanins, total polyphenols and antioxidant activity in amaranth and quinoa seeds and sprouts during their growth. Food Chemistry, 115(3), 994-998.

Diaz, J. M. R., Kirjoranta, S., Tenitz, S., Penttilä, P. A., Serimaa, R., Lampi, A. M. \& Jouppila, K. (2013). Use of amaranth, quinoa and kañiwa in extruded corn-based snacks. Journal of Cereal Science, 58(1), 59-67.

Ranhotra, G.S., Gelroth, J.A., Glaser, B.K., Lorenz, K. J. \& Johnson, D.L. (1993). Composition and protein nutritional quality of quinoa. Cereal chemistry, 70, 303-303.

Rizzello, C.G., Lorusso, A., Montemurro, M. \& Gobbetti, M. (2016). Use of sourdough made with quinoa (Chenopodium quinoa) flour and autochthonous selected lactic acid bacteria for enhancing the nutritional, textural and sensory features of white bread. Food microbiology, 56, 1-13.

Slinkard, K. \& Singleton, V.L. (1977). Total phenol analysis: automation and comparison with manual methods. American journal of enology and viticulture, 28(1), 49-55.

Tan, M. \& Yöndem, Z. (2013). İnsan ve Hayvan Beslenmesinde Yeni Bir Bitki: Kinoa (Chenopodium quinoa Willd.)/A New Crop for Human and Animal Nutrition: Quinoa (Chenopodium quinoa Willd.). Alınteri Zirai Bilimler Dergisi, 25(2).

Turkut, G.M., Cakmak, H., Kumcuoglu, S. \& Tavman, S. (2016). Effect of quinoa flour on gluten-free bread batter rheology and bread quality. Journal of Cereal Science, 69, 174-181.

Valencia-Chamorro, S.A. (2003). Quinoa. In 'Encyclopedia of food science and nutrition. Vol. 8'.(Ed. B Caballero) pp. 4895-4902. 